\title{
Congressional Abrogation of Indian Treaties: Reevaluation and Reform
}

\author{
Mike Townsend
}

We look at the moral or spiritual side of a treaty. . . . Treaties mean words that nobody can get around, get over, get under. -Richard Real Bird, Chairman, Crow Tribe

It is long settled that "the provisions of an act of Congress, passed in the exercise of its constitutional authority, . . . if clear and explicit, must be upheld by the courts, even in contravention of express stipulations in an earlier treaty" . . . . This Court [has] applied that rule to congressional abrogation of Indian treaties .... -United States v. Dion ${ }^{2}$

The treaties between the United States and the Indians ${ }^{3}$ constitute a

1. Remarks at the Philadelphia Ethical Society Symposium on American Indian Tribes and the United States Constitution (Oct. 12, 1987); see also V. Deloria, JR. \& C. LyTle, AMERICAN INDIANS, AMERICAN Justice 43 (1983) ("When the Indian nations treated with the United States government, they undoubtedly assumed that the negotiated agreements would endure "ad infinitum." "); Wilkinson \& Volkman, Judicial Review of Indian Treaty Abrogation: "As Long as Water Flows, or Grass Grows Upon the Earth"-How Long a Time Is That?, 63 CalIf. L. Rev. 601, 612 n.53 (1975) ("Indians continue to expect treaty promises to be honored. On the reservation, treaties are spoken of with a reverence that is equalled only by discussions of tribal sovereignty.").

2. 476 U.S. 734,738 (1986) (quoting Fong Yue Ting v. United States, 149 U.S. 698, 720 (1893)).

3. The Court concluded long ago that the Constitution recognizes the ability of the United States and the Indian nations to enter into treaties. See Worcester v. Georgia, 31 U.S. (6 Pet.) 515, 558-60 (1832).

Between 1789 and 1871, Indian treaties were negotiated and signed by the executive and consented to by the Senate. See 2 C. Butler, The Treaty Making Power of The United States $\$ 404$, at 198-99 (1902). In 1871, Congress passed a bill stating in part that no additional treaties were to be made with the Indians. Act of Mar. 3, 1871, ch. $120, \S 1,16$ Stat. 544, 566 (codified at 25 U.S.C. $\S$ $71(1982)$ ). This provision may have been a compromise resulting from the House's anger at being expected to appropriate money to implement the treaties even though it did not participate in their negotiation. See D. Getches \& C. Wilkinson, Federal Indian Law: Cases and Materials 110 (2d ed. 1986). Others suggest that it resulted from a belief that Indian sovereignty was no longer a viable notion. See Martone, American Indian Tribal Self-Government in the Federal System: Inherent Right or Congressional License?, 51 Notre Dame Law. 600, 606-07 (1976). The provision is usually seen as a notice by the House that it will refuse to appropriate money to implement Indian treaties. See, e.g., Antoine v. Washington, 420 U.S. 194, 201-03 (1975).

From 1871 until the end of the era of negotiated settlements with the Indians in 1909, agreements were negotiated and signed by the executive and consented to by simple majorities of both houses of Congress. See Note, Federal Indian Policy: A Violation of International Treaty Law, 4 W. ST. U.L. REv. 229, 237 n.38 (1977). These agreements have the full force of treaties. See Antoine v. Washington, 420 U.S. 194, 204 (1975); Dick v. United States, 208 U.S. 340, 359 (1908). Altogether, approxi- 
critical recognition and guarantee of Indian rights. They envision a "measured separatism"s for an important minority ${ }^{6}$ that is determined to maintain a distinct cultural and political identity. ${ }^{7}$ Non-treaty rights are fragile: The Supreme Court has held that Indians are not citizens within the meaning of the Fourteenth Amendment, ${ }^{8}$ and that Congress has "plenary power" over Indian affairs by virtue of its guardianship over their interests. ${ }^{9}$ Moreover, the United States has ended the formal negotiation process with the Indians, and apparently no further treaties will be concluded. ${ }^{10}$ Thus, Congress' power to abrogate ${ }^{11}$ the Indian treaties limits the Indians' ability to maintain their unique communities.

Notwithstanding the importance of the treaties, the Supreme Court has

mately 400 treaties and agreements were concluded. See C. WILKINSON, AMERICAN INDIANS, TimE, AND THE LAW 8 (1987).

4. See United States v. Winans, 198 U.S. 371, 381 (1905) (treaty "[is] not a grant of rights to the Indians, but a grant of rights from them-a reservation of those not granted").

5. See C. Wilkinson, supra note 3, at 14-19 (arguing that treaties guarantee substantial Indian independence as well as federal protection and provision of services); see also Worcester v. Georgia, 31 U.S. (6 Pet.) 515, 556-57 (1832) (discussing notion of separatism).

Indian treaties cover a wide range of subjects, including trade, extradition, war and peace, political sovereignty, territorial boundaries, hunting and fishing rights, relations with other countries, and general assistance benefits. See generally F. CoHEN, HANDBook of FEDERAL Indian LAw 38-46 (1942); Wilkinson \& Volkman, supra note 1, at 602-12; Note, supra note 3, at 237-38. Rights such as land occupancy are necessary for maintaining Indian culture and cannot be truly compensated for with money. See Wilkinson \& Volkman, supra note 1, at 604-07. Rights such as sovereignty are difficult to protect in a traditional constitutional framework. See Washington v. Confederated Bands and Tribes of the Yakima Indian Nations, 439 U.S. 463, 501 (1979) (rejecting due process challenge to congressional restriction of tribal sovereignty); United States v. Wheeler, 435 U.S. 313, 322-23 (1978) (tribes have no absolute constitutional right to autonomy). But see R. BARSH \& J. HENDERSON, The Road: Indian Tribes ANd Political LiberTy 261-62, 264-67 (1980) (arguing that tribal sovereignty should be protected as retained right under Ninth and Tenth Amendments); Newton, Federal Power over Indians: Its Sources, Scope, and Limitations, 132 U. PA. L. REv. 195, 261 (1984) (suggesting that apportionment and Indian commerce clauses recognize some rights of selfgovernment). Many treaties recognize and promise to protect tribal sovereignty. See id. at 262 \& n.385.

6. The 1980 census reported approximately 1.5 million Indians living in the United States. See Bureau of the Census, U.S. Dep't of Commerce, 11980 Census of Population ch. C, pt. 1, at 1-12 (1983). Roughly one-half live on-reservation. See D. Getches \& C. Wilkinson, supra note 3 , at 7 . Despite their relatively small numbers, Indian tribes and individuals control substantial land, energy, and mineral resources. See id. at 13, 614.

7. See V. Deloria, Jr., Behind the Trail of Broken Treaties: An Indian Declaration of INDEPENDENCE 250 (1974); V. Deloria, JR. \& C. Lytie, supra note 1, at xi-xiii; see also D. GETCHES \& C. Wilkinson, supra note 3, at 18-20 (quoting various authorities).

8. See Elk v. Wilkins, 112 U.S. 94, 102, 109 (1884). Some Indians were made citizens by treaties and statutes. See generally D. GeTChes \& C. WILKINSON, supra note 3, at 548-49. General citizenship was granted by the Indian Citizenship Act of 1924, ch. 233, 43 Stat. 253 (codified at 8 U.S.C. $\$$ 1401(b) (1982)).

9. See Lone Wolf v. Hitchcock, 187 U.S. 553, 565-68 (1903); United States v. Kagama, 118 U.S. 375,383 (1885). The guardian or "trust" relation can be traced to language contained in several early opinions. See Worcester v. Georgia, 31 U.S. (6 Pet.) 515, 561 (1832) (using analogy of "tributary" or "feudatory" state); Cherokee Nation v. Georgia, 30 U.S. (5 Pet.) 1, 17 (1831) (Marshall, C.J.) (stating that Indian nations are not foreign nations but "domestic dependent nations" and that "[t]heir relation to the United States resembles that of a ward to his guardian"). For a detailed history of the guardian relation, see Newton, supra note 5.

10. See supra note 3 .

11. In this Note, "abrogation" is used as a general term to refer to the elimination of treaty obligations by any means. See A. McNair, The LAw of Treaties 491 (1961). 
repeatedly recognized the power of Gongress to abrogate them unilaterally when Congress has clearly expressed its intent to do so. ${ }^{12}$ However, the Court has never clearly described the basis for this power. In 1871, the Court suggested in The Cherokee Tobacco ${ }^{13}$ that congressional abrogation is an application of the last-in-time rule, under which a treaty may supersede a prior statute and a statute may supersede a prior treaty. ${ }^{14}$ Thirtytwo years later, the Court offered two other justifications in Lone Wolf $v$. Hitchcock. ${ }^{15}$ Lone Wolf hints that abrogation can be justified by Congress' plenary power over Indian affairs. ${ }^{16}$ In addition, the decision suggests that abrogation can be viewed as an application of the international law doctrine of rebus sic stantibus, under which one party may terminate a treaty due to a fundamental change in circumstances. ${ }^{17}$

This Note argues that none of these three justifications is persuasive and that the Court should give increased protection to Indian treaties. Section I provides the relevant background on treaties. Section II examines the justifications and concludes that none of them is persuasive. Finally, Section III proposes that congressional abrogation be limited by a "lastin-time plus" rule that would require Congress to provide both an express statement of abrogation and an acceptable reason as measured by the requirements for treaty termination under international law. This standard acknowledges the extensive congressional power over Indian affairs, while also recognizing the importance of the treaties and the unique status and history of the Indian peoples. ${ }^{18}$

\section{BACKGROUND ON TREATIES}

A treaty may be thought of as a contract between two or more states. ${ }^{19}$ Under the Constitution, treaties are made by the President with the advice and consent of the Senate. ${ }^{20}$ The Court also has upheld "agreements" made by the President with the consent of both houses of Congress. These

12. See, e.g., United States v. Dion, 476 U.S. 734, 738 (1986).

13. 78 U.S. (11 Wall.) 616 (1871).

14. Id. at 621 .

15. 187 U.S. 553 (1903).

16. Id. at $565-66$.

17. Id. at 566 .

18. Commentators suggest a variety of ways to protect Indian treaty rights. Some argue for increased protection under the Constitution. See supra note 5 . Some would rely on an expanded notion of the guardian relation. See Chambers, Judicial Enforcement of the Federal Trust Responsibility to Indians, 27 STAN. L. REv. 1213, 1227 (1975). Others would require an express statement of congressional intent in statutes that abrogate Indian treaty rights. See, e.g., Wilkinson \& Volkman, supra note 1 , at 645 . Still others assert that any abrogation of treaty rights is a per se violation of international law. See, e.g., Note, supra note 3, at 268.

19. See, e.g., Trans World Airlines v. Franklin Mint, 466 U.S. 243, 253 (1984); Fong Yue Ting v. United States, 149 U.S. 698, 720 (1893); Foster v. Neilson, 27 U.S. (2 Pet.) 253, 314 (1829); 1 L. OPPENHEIM, INTERNATIONAL LAW 877 (H. Lauterpacht 8th ed. 1955).

20. U.S. Const. art. II, $\S 2$, cl. 2. 
agreements have the full force of treaties ${ }^{21}$ and differ only in that both houses of Congress consent. ${ }^{22}$

The international law doctrine of pacta sunt servanda requires that parties to a treaty perform their obligations in good faith. ${ }^{23}$ Nevertheless, international law provides that treaties can be terminated for the following reasons: termination under the terms of the treaty or by consent of the parties; implied termination by a subsequent treaty; denunciation or withdrawal from certain types of treaties, such as treaties of alliance and commerce; termination as a consequence of a breach by another party; termination due to a fundamental change in circumstances; and, in certain situations, termination due to war between the parties. ${ }^{24}$ Unilateral termination requires that formal notice be given by the terminating party. ${ }^{25}$ In the United States, the power to terminate treaties has been claimed for Congress, the President, and the President-and-Senate, and the location of the power has been, and continues to be, hotly contested. ${ }^{26}$

Treaties (or their provisions) are either "self-executing" or "non-selfexecuting." 27 The Court has interpreted the supremacy clause ${ }^{28}$ to mean that self-executing treaties automatically become the supreme law of the land without the need of any legislative action. ${ }^{29}$ Thus, they are superior

21. See Antoine v. Washington, 420 U.S. 194, 204 (1975); Dick v. United States, 208 U.S. 340 , 359 (1908). The Court also has recognized executive agreements made by the President alone. See United States v. Pink, 315 U.S. 203, 229-30 (1942); United States v. Belmont, 301 U.S. 324, 330-31 (1937). Executive agreements are beyond the scope of this Note.

22. In this Note, the terms "treaty" and "agreement" are used interchangeably.

23. See Restatement (Third) of the Foreign Relations Law of THE United States $\S$ 321 \& comment a (1986) [hereinafter RESTATEMENT (ThIRD)]; A. MCNaIR, supra note 11, at 493-505; 1 L. Oppenheim, supra note 19, at $881 \mathrm{n} .1$; G. Schwarzenberger, A Mandal of INTERnational LAw 148-49 (5th ed. 1967). See generally Wehberg, Pacta Sunt Servanda, 53 AM. J. INT'L L. 775 (1959).

24. See generally Restatement (ThIRD), supra note 23, $\$ \$ 331-336$; International Law Commission Report, [1966] 2 Y.B. INT'L L. CoMM'N 1, U.N. Doc. A/CN.4/SER.A/1966/Add.1; 5 G. HaCkWorTh, Digest of INTERnational. LAW 297-390 (1943); A. MCNaIR, supra note 11, at 493-589; 1 L. OPPENHEIM, supra note 19 , at 936-49.

25. See Restatement (ThIRD), supra note 23, § 337; Vienna Convention on the Law of Treaties, opened for signature May 23, 1969, art. 65 \& art. 67, para. 2, 1155 U.N.T.S. 331 [hereinafter Vienna Convention]; $1 \mathrm{~L}$. Oppenheim, supra note 19, at 938-42. The United States is not a party to the Convention, but the President, in submitting the Convention to the Senate, stated that the Convention "is already generally recognized as the authoritative guide to current treaty law and practice." $S$. Exec. Doc. L., 92d Cong., 1st Sess. 1 (1971).

26. See generally Senate Comm. on Foreign Relations, 95th Cong., 2D Sess., Termination of Treaties: The Constitutional allocation of Power (Comm. Print 1978); D. Adler, The Constitution and the Termination of Treaties (1986); L. Henkin, Foreign AfFAIRS AND THE CONSTITUTION 167-71 (1972).

27. Whether a treaty is self-executing is a matter of interpreting the agreement in light of its subject matter, the nature of its obligations, and the circumstances surrounding its adoption. See RESTATEMENT (ThIRD), supra note $23, \S 111$ comments h, i \& reporters' notes 5,6 ; L. HeNkIN, supra note 26, at 158-59. For general discussions of self-executing and non-self-executing treaties, see id. at 156-61; L. Henkin, R. Pugh, O. Schachter \& H. Smit, International Law: Cases and Materials 198-205 (2d ed. 1987).

28. U.S. CoNST. art. VI, cl. 2.

29. See Cook v. United States, 288 U.S. 102, 118-19 (1933); The Chinese Exclusion Case, 130 U.S. 581, 600 (1889); Whitney v. Robertson, 124 U.S. 190, 194 (1888); Chew Heong v. United States, 112 U.S. 536, 540 (1884); Foster v. Neilson, 27 U.S. (2 Pet.) 253, 314 (1829). 
to state laws and constitutions ${ }^{30}$ and on a par with federal statutes. ${ }^{31}$ In the case of non-self-executing treaties, it is the implementing legislation that is the supreme law of the land..$^{32}$ Thus, both self-executing and nonself-executing treaties may have domestic consequences.

There are three ways for Congress to repeal the domestic effect of a treaty. First, Congress may be able to terminate the treaty. ${ }^{33}$ Second, Congress can repeal the legislation implementing a non-self-executing treaty. ${ }^{34}$ Finally, the Court has developed a last-in-time rule for self-executing treaties, under which a treaty may supersede a prior statute and a statute may supersede a prior treaty. ${ }^{35}$ In the latter two cases, the international obligations contained in the treaty remain; although domestic courts will give effect to the repeal, the United States remains obligated under international law. ${ }^{36}$ The last-in-time rule is subject to a "clear statement" principle that requires a clear intent to supersede. ${ }^{37}$

Indian and international treaties are the same in many important respects. Indian treaties are contracts between two sovereign states, ${ }^{38}$ are the supreme law of the land, ${ }^{39}$ and may be abrogated by unilateral congressional action. ${ }^{40}$ The status of the Indian nations, however, is the subject of

30. See Hauenstein v. Lynham, 100 U.S. 483, 490 (1880).

31. See Whitney v. Robertson, 124 U.S. 190, 194 (1888); Head Money Cases, 112 U.S. 580, 598 (1884); Chew Heong v. United States, 112 U.S. 536, 540 (1884).

32. See RestatemENT (ThIRD), supra note 23, §111 comment h; L. HENkIN, supra note 26, at 157 n.t.

33. See supra text accompanying note 26 .

34. See Whitney v. Robertson, 124 U.S. 190, 194 (1888). Congress may be able to avoid entirely the domestic effect of a non-self-executing treaty by refusing to pass the implementing legislation. See L. Henkin, supra note 26, at 161-62. If Congress fails to pass the implementing legislation, however, the United States remains obligated under international law. See Restatement (THIRD), supra note 23, § 111 comment h; Preuss, On Amending the Treaty-Making Power: A Comparative Study of the Problem of Self-Executing Treaties, 51 Mich. L. REv. 1117, 1139-41 (1953).

35. See, e.g., Whitney v. Robertson, 124 U.S. 190, 194 (1888). For detailed discussions of the historical development of this rule in the United States, see L. ERADES \& W. Gould, The Rela-

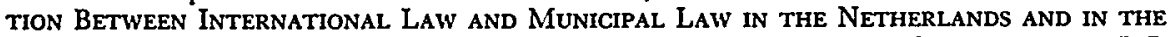
UNited STates 372-88, 419-56 (1961); Spear, The Conflict of Treaties and Laws, 22 AlB. L.J. 226 (1880). Other countries take a variety of approaches. See generally L. HENkIN, R. PuGH, O. SCHACHTER \& H. SMT, supra note 27, at 207 (discussing status of last-in-time rule in France, Italy, Germany, and the Netherlands).

36. See Pigeon River Improvement Slide \& Boom Co. v. Cox, Ltd., 291 U.S. 138, 160 (1934); RESTATEMENT (ThIRD), supra note 23, $\$ 115$ comment b; 5 G. HACKWORTH, supra note 24 , at 185-86, 194-95, 324-25.

37. See Cook v. United States, 288 U.S. 102, 120 (1933); Fong Yue Ting v. United States, 149 U.S. 698, 720 (1893).

38. See, e.g., Washington v. Washington State Commercial Passenger Fishing Vessel Ass'n, 443 U.S. 658,675 (1979).

39. See, e.g., Antoine v. Washington, 420 U.S. 194, 204 (1975); United States v. Forty-three Gallons of Whiskey, 93 U.S. 188, 196 (1876); Worcester v. Georgia, 31 U.S. (6 Pet.) 515, 558-60 (1832).

40. See, e.g., United States v. Dion, 476 U.S. 734, 738 (1986). The loss of Indian rights due to abrogation is ameliorated to some degree by the Fifth Amendment's takings clause, which has been construed to require that compensation be given for certain abrogations. See, e.g., United States v. Sioux Nation of Indians, 448 U.S. 371, 401-23 (1980); Shoshone Tribe of Indians v. United States, 299 U.S. 476, 497 (1937). This Note focuses on the abrogation of self-executing portions of Indian treaties. The refusal to implement non-self-executing provisions and the supersession of implementing legislation are beyond the scope of this Note. 
much debate. Some commentators claim that many Indian nations qualify as "states" under international law. ${ }^{41}$ The Court has not gone this far"2 and recently described Indian sovereignty to be of a "unique and limited character."43 Consequently, the Court treats Indian and international treaties differently in two major respects, both of which extend more protection to Indian treaties.

First, the Court has been less willing to infer abrogations of Indian treaties than of international treaties. ${ }^{44}$ However, it has had some trouble deciding what form a clear statement principle should take in the Indian context. At various times, the Court has adopted the following tests: abrogation requires a showing of clear legislative intent; abrogation will not be lightly imputed; abrogation will be found only after construing the statute in favor of the treaty; and abrogation is subject to an "express statement" principle that requires an explicit legislative reference to treaty rights. ${ }^{45}$ In its most recent statement, the Court required "clear evidence that Congress actually considered the conflict between its intended action on the one hand and Indian treaty rights on the other, and chose to resolve that conflict by abrogating the treaty. ${ }^{.46}$

Second, the Court applies traditional contract principles in interpreting international treaties, ${ }^{47}$ but it has developed special canons of construction for Indian treaties: ambiguous expressions are resolved in favor of the Indians; ${ }^{48}$ treaties are interpreted as the Indians themselves would have understood them; ${ }^{48}$ and treaties are liberally construed in favor of the Indians. ${ }^{\text {so }}$

41. See, e.g., Clinebell \& Thomson, Sovereignty and Self-Determination: The Rights of Native Americans Under International Law, 27 Buffalo L. Rev. 669 (1978); Note, supra note 3.

42. The Court early on rejected the notion that Indian nations possessed the full sovereignty of foreign nations. See Worcester v. Georgia, 31 U.S. (6 Pet.) 515, 561 (1832) (using analogy to "tributary" or "feudatory" states); Cherokee Nation v. Georgia, 30 U.S. (5 Pet.) 1 (1831) (Indian nations are not foreign nations within meaning of Article III); Johnson \& Graham's Lessee v. M'Intosh, 21 U.S. (8 Wheat.) 543, 574 (1823) (Indians' "rights to complete sovereignty, as independent nations, [are] necessarily diminished"). However, the Court has held that tribal sovereignty predates the Constitution and that the Indian nations possess, in addition to the federal government and the states, a third source of sovereignty in the United States. See United States v. Wheeler, 435 U.S. 313, 319-32 (1978); Talton v. Mayes, 163 U.S. 376, 384 (1896). For a brief introduction to the complicated history of Indian sovereignty, see C. WILKINSON, supra note 3, at 54-63.

43. United States v. Wheeler, 435 U.S. 313, 323 (1978). The Court also stated that Indian sovereignty is subject to "complete defeasance" by Congress. Id.

44. See Wilkinson \& Volkman, supra note 1, at 622 .

45. See generally id. at 623-45.

46. United States v. Dion, 476 U.S. 734, 740 (1986).

47. See, e.g., Rocca v. Thompson, 223 U.S. 317, 331-32 (1912); Tucker v. Alexandroff, 183 U.S. 424,437 (1902).

48. See, e.g., McClanahan v. Arizona State Tax Comm'n, 411 U.S. 164, 174 (1973).

49. See, e.g., Choctaw Nation v. Oklahoma, 397 U.S. 620, 631 (1970).

50. See, e.g., Tulee v. Washington, 315 U.S. 681, 684-85 (1942). 


\section{Congressional Abrogation of Indian Treaties: REEVALUATION}

\section{A. The Cherokee Tobacco: The Last-in-Time Rule}

The Cherokee Tobacco ${ }^{51}$ involved the conflict between a treaty provision guaranteeing to Cherokees living within their nation the right to manufacture and sell tobacco products without "paying any tax thereon,"32 and a subsequent statute imposing taxes on tobacco "produced anywhere within the exterior boundaries of the United States." such conflicts arise because the Constitution declares self-executing treaties to be the supreme law of the land. ${ }^{54}$ It acknowledged that the conflict is "not settled by the Constitution,"ss but asserted that there was "not . . . any doubt as to its proper solution." "In what was its first general pronouncement on the relation between treaties and statutes, the Court held that such conflicts would be decided by the last-in-time rule, under which, as a matter of domestic law, "[a] treaty may supersede a prior act of Congress, and an act of Congress may supersede a prior treaty."

51. 78 U.S. (11 Wall.) 616 (1871).

52. Treaty of July 19,1866 , art. X, 14 Stat. $799,801$.

53. Internal Revenue Act of July 20, 1868, ch. 186, § 107, 15 Stat. 125, 167.

54. 78 U.S. (11 Wall.) at 620 .

55. Id. at 621 .

56. Id.

57. Id. The Court relied on Foster v. Neilson, 27 U.S. (2 Pet.) 253 (1829), for the proposition that a treaty may supersede a prior act of Congress, and on two circuit court opinions, Taylor v. Morton, 23 F. Cas. 784 (C.C.D. Mass. 1855) (No. 13,799), affd, 67 U.S. (2 Black) 481 (1862), and In re Clinton Bridge, 5 F. Cas. 1060 (C.C.D. Iowa 1867) (No. 2900), aff d, 77 U.S. (10 Wall.) 454 (1870), for the proposition that an act of Congress may supersede a prior treaty.

Foster involved a suit to recover certain lands claimed under a Spanish grant that was assertedly ratified by treaty. The Court rejected this argument, finding the treaty to be non-self-executing. 27 U.S. (2 Pet.) at 315. The Court went on to state, without explanation or support, that statutes and self-executing treaties are equivalent, and that had the treaty been self-executing it would have superseded any prior inconsistent statutes. Id.

Taylor involved the conflict between a commercial treaty and a subsequent tariff act. Justice Curtis, sitting as Circuit Justice, found the treaty to be non-self-executing and held that Congress was free to repeal its implementing legislation. $23 \mathrm{~F}$. Cas. at $787-88$. He went on to offer a lengthy discussion of treaty-statute conflicts. The Constitution, he noted, does not resolve the conflict. Id. at 785 . The starting point is to examine the "nature and objects of each species of law" and the "authority from which each emanated." Id. He went on to state, without explanation or support, that the issue is "solely a matter of [domestic] law." Id. He argued that if the only way to undo the domestic effect of a treaty was to obtain the consent of the other party, the country would be placed in the absurd position of being dependent on a foreign government for its domestic law. Id. at 786. Thus, there must be the domestic power to repeal the domestic effect of a treaty. That Congress possesses it follows from the power to issue a declaration of war, which would automatically repeal certain provisions of treaties with the hostile party, and the power to regulate commerce, the subject matter of the treaty in question. Id. Curtis cited no authority for his position.

Clinton Bridge involved the conflict between a statute declaring the bridge to be a lawful structure and prior treaties providing for the free and unobstructed navigation of the Mississippi. In resolving the issue in favor of the statute, Justice Miller, sitting as Circuit Justice, relied mainly on separation of powers concerns. He argued that such conflicts involved political questions. $5 \mathrm{~F}$. Cas. at 1062. Moreover, if the judicial department could give effect to treaties in the face of subsequent statutes, "it could annul declarations of war, suspend the levy of armies, and become a great international arbiter." Id. As support for his position, Miller cited The Amiable Isabella, 19 U.S. (6 Wheat.) 1 (1821). This latter case did not discuss the issue at all, although it had been raised during arguments, and one 
this regard, the Gourt saw no difference between Indian treaties and international treaties, ${ }^{\mathbf{8}}$ but it noted that there were special "considerations of humanity and good faith" involved in the observance of Indian treaties. ${ }^{58}$ The Court nonetheless declared that such conflicts were political questions and suggested that the proper redress was an appeal to Congress. ${ }^{60}$

\section{B. General Discussion of the Last-in-Time Rule}

This section focuses on the general arguments surrounding the last-intime rule. The next section considers these arguments in the context of Indian treaties. The general arguments can be grouped into three categories: international law arguments, constitutional law arguments, and arguments arising from prudential concerns about treaties. ${ }^{61}$

The relevant international law arguments concern the relation of international law to domestic law, the character of sovereignty, and the nature of treaties. There are two main approaches to the relation of international law to domestic law. ${ }^{62}$ One argues that the two systems are completely separate and that international law can be applied domestically only when it has been incorporated by the domestic organs of government. ${ }^{63}$ Once incorporated, international law is subject to the limitations applicable to all domestic law and may be repealed for domestic purposes by subsequent domestic action. ${ }^{64}$ The second approach considers the two systems to be part of a single legal order in which domestic law derives its authority from international law and stands in a lower position in the hierarchy of legal systems. ${ }^{65}$ The United States appears to have adopted the first

counsel had offered his opinion that a later statute must prevail. Id. at 65 .

58. 78 U.S. (11 Wall.) at 621.

59. Id.

60. Id.

61. Because this Note focuses on abrogation of Indian treaties, the discussion of these arguments concentrates on the power of Congress to supersede treaties by subsequent statute. In any case, there is only one case in which the Court held that a treaty provision repealed a prior statute. See $\mathrm{L}$. Henkin, supra note 26, at 164, 411-12 n.113 (discussing Cook v. United States, 288 U.S. 102 (1933)). The Attorney General has taken the position that an Indian treaty supersedes a prior statute. 13 Op. Att'y Gen. 354 (1870). The fact that only one case has held a statute to be superseded by a treaty has been used to support the notion that statutes are superior to treaties. See Note, Congressional Power to Abrogate the Domestic Effect of a United Nations Treaty Commitment: Diggs v. Schultz (D.C. Cir. 1972), 13 Colum. J. TRansnat'L L. 155, 158 (1974). The question here, however, is whether the established practice is fully justified.

62. See generally L. Henkin, R. Pugh, O. Schachter \& H. SMrT, supra note 27, at 140-56; 1 L. Oppenheim, supra note 19, at 37-39; J. STARKe, AN InTroduction to International Law 76-100 (7th ed. 1972); Henkin, The Constitution and United States Sovereignty: A Century of Chinese Exclusion and Its Progeny, 100 HaRv. L. Rev. 853, 864-66 (1987).

63. See L. Henkin, R. Pugh, O. Schachter \& H. Smit, supra note 27 , at 140-41.

64. See id. This idea underlies the statements in Taylor v. Morton, 23 F. Cas. 784, 785 (C.C.D. Mass. 1855) (No. 13,799), affd, 67 U.S. (2 Black) 481 (1862), that the preliminary inquiry in treaty-statute conflicts is to consider "the nature and objects of each species of law," and that the issue involved in such conflicts is "solely a question of [domestic], as distinguished from [international] law."

65. See L. Henkin, R. Pugh, O. Schachter \& H. SMrt, supra note 27, at 140. 
approach, ${ }^{68}$ but self-executing treaties are incorporated automatically. ${ }^{67}$ The last-in-time rule is clearly suspect under the second approach. The first approach does not answer the question of the extent to which treaty obligations may bind a domestic government, ${ }^{68}$ and it does not specify the process required for domestic repeal.

A second type of argument starts with the premise that certain powers belong to a sovereign qua sovereign and may not be abandoned or surrendered. Therefore, to the extent that the Constitution commits these powers to Congress, legislation implementing these powers will be given effect, any treaty to the contrary notwithstanding. The last-in-time rule merely recognizes this principle. ${ }^{69}$ But treaties are by definition contracts in which nations agree to restrict their sovereignty, ${ }^{70}$ and the mere fact that nations regularly enter into treaties undercuts the premise of the argument. Moreover, the argument implies that there are no international obligations under certain types of treaties, a position specifically rejected by pacta sunt servanda. ${ }^{71}$ The argument at best supports a right of abrogation, but it does not address the question of what process is required for domestic repeal. ${ }^{72}$

By its very nature, a treaty must concern all parties to the agreement. ${ }^{73}$ Thus, if state A writes a purely domestic law into an agreement in order to circumvent its own domestic government, and state B cooperates by merely signing the agreement, then the agreement would not constitute a treaty under international law. ${ }^{74}$ To this extent, it might be argued, domestic application of treaties is suspect and the last-in-time rule provides a "checking" function. However, there is no a priori reason why domestic matters are not of mutual concern. In addition, the argument loses much of its force when applied to the United States, where the Senate or the full Congress must give its consent. ${ }^{\mathbf{7 s}}$

The relevant constitutional arguments about the last-in-time rule center on the text, history, and structure of the Constitution. Except for the order in which they are presented, the text of the supremacy clause does not

66. See RestateMENT (ThIRD), supra note 23, pt. I, ch. 2, introductory note; Henkin, supra note 62 , at 865-66.

67. See cases cited supra note 29 .

68. See Henkin, supra note 62, at 864-71.

69. See Mormon Church v. United States, 136 U.S. 1, 42 (1890). The Court has often relied on this argument in applying the last-in-time rule to immigration cases. See Fong Yue Ting v. United States, 149 U.S. 698, 707, 711 (1893); Nishimura Ekiu v. United States, 142 U.S. 651, 659 (1892); The Chinese Exclusion Case, 130 U.S. 581, 609 (1889). For a criticism of the argument in the context of immigration treaties, see Henkin, supra note 62 .

70. See L. Henkin, supra note 26 , at 150-51, 411 n.111.

71. See sources cited supra note 23 .

72. See L. HENKIN, supra note 26 , at $411 \mathrm{n} .111$.

73. See id. at $142-43$.

74. See id.

75. It was precisely such concerns that led to the Senate's role in the treaty-making process. See D. Adler, supra note 26, at 85-88; The Federalist No. 75 (A. Hamilton). 
distinguish between treaties and statutes as the supreme law of the land. ${ }^{78}$ It has been suggested that this implies that treaties and statutes are equivalent and that therefore the later in time should apply. ${ }^{77}$ However, the supremacy clause also does not distinguish between treaties and statutes on the one hand and the Constitution on the other, and it is clear that the last-in-time rule does not apply to statutes or treaties vis-à-vis the Constitution. ${ }^{78}$

Neither the framers nor the ratifying conventions seem to have given much thought to the potential conflict between treaties and statutes. ${ }^{79}$ The historical materials suggest that Jay and Hamilton believed that treaties were supreme with respect to both prior and subsequent statutes, ${ }^{80}$ and that Madison thought the opposite. ${ }^{81}$ The first extended discussion of the issue occurred in 1796 during the House debates on the Jay treaty, and there was no consensus. ${ }^{82}$

Structural arguments about the last-in-time rule focus on the separation of powers. One argument assumes that a treaty cannot increase, decrease, redistribute, or barter away the powers of any of the three branches of government. ${ }^{83}$ Therefore, no treaty can restrict the power of future Congresses to exercise their lawmaking functions. ${ }^{84}$ However, this argument fails to distinguish between treaties granting powers that the Constitution specifically does not grant ${ }^{85}$ from those that represent agreements not to exercise powers already constitutionally granted. ${ }^{86}$ With respect to the latter, the Constitution specifically provides for treaties, ${ }^{87}$ which are by defi-

76. The argument has been made that because treaties are listed third, they are superseded by both prior and subsequent statutes. See 5 ANNALS of Congress 450 (1796) (remarks of Rep. Swanwick). Such an argument is contrary to the last-in-time rule. Moreover, one wonders how far the argument should be carried. Consider, for example, that the judicial power is described in Article III of the Constitution, and the legislative power and executive power in Articles I and II, respectively.

77. This argument underlies the Court's early statements that a self-executing treaty is "to be regarded in courts of justice as equivalent to an act of the legislature," and that it would repeal "those acts of congress which [are] repugnant to it." Foster v. Neilson, 27 U.S. (2 Pet.) 253, 314-15 (1829).

78. See Reid v. Covert, 354 U.S. 1, 16-17 (1957) (treaties); Marbury v. Madison, 5 U.S. (1 Cranch) 137, 180 (1803) (statutes); L. HeNkIN, supra note 26, at 163; Henkin, supra nate 62, at 871-72; see also E. Byrd, JR., Treaties and Executtve Agreements in the United States: Their Separate Roles AND Limitations 23, 38-41 (1960) (arguing that framers assumed that Constitution provides limits on treaty-making powers); L. HENkIN, supra note 26, at 139 (executive and legislative branches routinely recognize same limitation).

79. See L. ERades \& W. Gould, supra note 35, at 373, 419-21.

80. See 1 C. Butler, supra note $3, \S 313$, at 449 (discussing views of Hamilton); L. ERAdEs \& W. Gould, supra note 35, at 379-80, 419, 421-23 (discussing views of Hamilton and Jay).

81. See L. ERADEs \& W. Gould, supra note 35, at 377 (discussing views of Madison).

82. See E. BYRD, JR., supra note 78, at 50-52 (analyzing debates); L. ERADES \& W. Gould, supra note 35 , at $380-84,424-26$ (same).

83. See, e.g., R. Ghosh, Treaties and Federal Constitutions: Their Mutual Impact 150-63 (1961).

84. See id. at 152.

85. Such treaties are invalid. See Reid v. Covert, 354 U.S. 1, 16-17 (1957).

86. Hamilton recognized this distinction. See A. Hamilton, Camillus No. 36, in 6 The Works of Alexander Hamilton 165-71 (H. Cabot Lodge ed. 1904).

87. See U.S. ConST. art. II, § 2, cl. 2; U.S. ConST. art. III, § 2, cl. 1; U.S. ConST. art. VI, cl. 2. 
nition contracts in which nations agree to restrict their sovereignty ${ }^{88}$ It also provides that some congressional actions, such as the passage of a statute raising the salaries of sitting Article III judges, do restrict the power of future Congresses to exercise their lawmaking functions. ${ }^{89}$ This structural argument at best is similar to the argument from sovereignty discussed above, and similar responses can be given..$^{80}$

A second separation of powers argument notes that both Congress and the President have foreign affairs powers, an overlap that allows for flexibility and checks and balances. ${ }^{91}$ The last-in-time rule recognizes this overlap by enforcing the last will of the political sovereign. ${ }^{92}$ This is the strongest constitutional argument for the last-in-time rule, and it has great force in the case of a foreign affairs conflict between the executive and legislative branches.

A final structural argument asserts that the last-in-time rule merely says that treaty-statute conflicts are inherently political and should be left to the political branches. ${ }^{93}$ However, there is some question about the nature and scope of the political question doctrine, ${ }^{94}$ and in the case of treaties this argument seems to be nothing more than a reformulation of the previous separation of powers argument. ${ }^{95}$

88. See L. Henkin, supra note 26, at 150-51, 411 n.111.

89. See O'Donoghue v. United States, 289 U.S. 516, 551 (1933).

90. See supra text accompanying notes 69-72.

91. See, e.g., L. Henkin, supra note 26, at 27-28, 32-35, 92; McDougal \& Lans, Treaties and Congressional-Executive or Presidential Agreements: Interchangeable Instruments of National Policy: I, 54 YALE L.J. 181, 185-87, 202-10, 217-21, 238-55 (1945).

92. See L. HENkIN, supra note 26, at 33; McDougal \& Lans, supra note 91, at 220-21 \& n.31.

93. See, e.g., Whitney v. Robertson, 124 U.S. 190, 194 (1888) ("If the country with which the treaty is made is dissatisfied with the action of the legislative department, it may present its complaint to the executive head of the government, and take such other measures as it may deem essential for the protection of its interests. The courts can afford no redress. Whether the complaining nation has just cause of complaint, or our country was justified in its legislation, are not matters for judicial cognizance.").

94. See, e.g., Henkin, Is There a "Political Question" Doctrine?, 85 YALE L.J. 597 (1976). For a criticism of the doctrine as applied in treaty cases, see Henkin, Lexical Priority or "Political Question": A Response, 101 HaRv. L. REv. 524, 529-30 (1987) [hereinafter Henkin, Response].

95. Cf. Wechsler, Toward Neutral Principles of Constitutional Law, 73 HARv. L. REv. 1, 7-8 (1959) ("IA]ll the [political question] doctrine can defensibly imply is that the courts are called upon to judge whether the Constitution has committed to another agency of government the . . . determination of the issue raised. ....").

Professor Westen introduces an interesting twist to this argument by suggesting a different interpretation of the last-in-time rule. See Westen, The Place of Foreign Treaties in the Courts of the United States: A Reply to Louis Henkin, 101 HARV. L. REv. 511 (1987). Under his interpretation, treaties are superior to statutes, $i d$. at 512 , and a person with a claim based on the breach of international commitments is entitled to relief, id. at 516 . But the Constitution requires courts to follow subsequent statutes, $i d$. at 512 , and relief must be sought from the political branches, $i d$. at $512,516,520-21$. As support for this position, Westen relies on the Court's statements in Indian and international treaty cases that such claims are non-justiciable, $i d$. at 516-17, and on an assertion that in 1789 nations did not open their own courts to suits against themselves for the violation of treaties, id. at 521 .

In response, several observations can be made. The Constitution specifically extends federal question jurisdiction to cases arising under treaties. U.S. CoNST. art. III, § 2, cl. 1. Later decisions have substantially modified the notion that Indian treaty claims are non-justiciable. See supra note 40; infra notes 121-32 and accompanying text. With respect to Westen's historical assertions, it should be noted that prize courts did provide a domestic forum for certain types of international law claims 
Other arguments for the last-in-time rule stem from prudential concerns about treaties. First, the Court has indicated in at least one case that allowing a statute to supersede a prior treaty is more democratic because it recognizes the input of the House. ${ }^{98}$ However, this argument is nothing more than a complaint that the House was left out of the treaty-making process. ${ }^{97}$ The argument addresses neither agreements consented to by both houses of Congress nor superseding statutes passed over a veto. Moreover, it calls into question whether a treaty consented to only by the Senate can supersede a prior statute. ${ }^{98}$ Second, several opinions have argued that the last-in-time rule avoids the absurdity of having domestic law at the mercy of a foreign government. ${ }^{99}$ However, this argument justifies at most a right of abrogation, and it does not specify the process required for domestic repeal. Third, it might be suggested that the rule allows Congress to abrogate the harmful effects of a treaty while preserving the "clean hands" of the President. But the President's feelings generally are well-known, and the argument makes little sense if the President signs the superseding statute. ${ }^{100}$

Perhaps the best explanation of the last-in-time rule comes from the concerns underlying its development in the nineteenth century. The rule emerged in a time when the Court was very reluctant to strike down federal statutes. ${ }^{101}$ In addition, many of the early cases in which it was ap-

against the sovereign. See R. Pares, Colonial Blockade and Neutral Rights 1739-1763 (1938); see also Henkin, Response, supra note 94, at 530-31 (describing other practices). Finally, interpreting Article III by considering eighteenth century foreign courts is problematic. Such an approach casts considerable doubt on the doctrine of judicial review. For other criticisms of Westen's view, see Henkin, Response, supra note 94.

Even accepting Westen's basic position, it is plausible that the framers created the foreign affairs overlap in part to provide the checks and balances necessary to protect the integrity of this dispute resolution process. Thus, the overlap in foreign affairs is part of the core support of either interpretation of the last-in-time rule.

96. See Head Money Cases, 112 U.S. 580, 599 (1884).

97. For a discussion of the reasons that the House was left out of the treaty-making process, see D. ADLER, supra note 26 , at $85-88,98-101$. The fact that the House was left out of the process has been used to argue that Congress should not be able to vary a treaty's effect by subsequent statute. See Note, supra note 61, at 159.

98. See Eule, Temporal Limits on the Legislative Mandate: Entrenchment and Retroactivity, 1987 AM. B. Found. REs. J. 379, 425 n.213.

99. In Taylor v. Morton, 23 F. Cas. 784, 786 (C.C.D. Mass. 1855) (No. 13,799), affd, 67 U.S. (2 Black) 481 (1862), Justice Curtis, sitting as Circuit Justice, argued, "That the constitution was designed to place our country in this helpless condition, is a supposition wholly inadmissible." See also The Chinese Exclusion Case, 130 U.S. 581, 602 (1889) (arguing that rule could not be otherwise without "deeply affecting [the nation's] independence"); Dred Scott v. Sandford, 60 U.S. (19 How.) 393, 629-30 (1857) (Curtis, J., dissenting) (repeating argument given in Taylor).

100. The President may be able to claim that she is forced to sign a particular statute because it contains other provisions.

101. At the time that the Court announced the last-in-time rule in The Cherokee Tobacco, it had struck down only three federal laws in Hepburn v. Griswold, 75 U.S. (8 Wall.) 603 (1870) (striking down Legal Tender Act), overruled, The Legal Tender Cases, 79 U.S. (12 Wall.) 457 (1871); Dred Scott v. Sandford, 60 U.S. (19 How.) 393 (1857) (striking down part of Missouri Compromise); and Marbury v. Madison, 5 U.S. (1 Cranch) 137 (1803) (striking down part of Judiciary Act of 1789). 
plied involved commercial treaties, ${ }^{102}$ a subject of particular concern to the framers because of the importance of commercial affairs. ${ }^{103}$

\section{Critique of the Last-in-Time Rule Justification}

The view that congressional abrogation of Indian treaties is an application of the last-in-time rule is problematic for several reasons. First, the rule generally leaves the non-domestic obligations of treaties intact, ${ }^{104}$ but there is no suggestion in any decision that federal obligations contained in Indian treaties survive abrogation in any way. In other words, a direct analogy to the rule might suggest that statutes abrogate off-reservation rights but not on-reservation rights. ${ }^{105}$

Second, the rule is particularly suspect when applied to Indian treaties. The strongest arguments favoring the rule involve the separation of powers and prudential concerns about treaties. ${ }^{106}$ However, the separation of powers argument does not apply because the doctrine of plenary congressional power precludes the type of overlap that exists in foreign affairs. ${ }^{\mathbf{1 0 7}}$ Prudential arguments are also unavailing. There is little worry about our domestic law being held hostage: Indians have been willing to negotiate when treaties have become outdated. ${ }^{108}$ The clean hands of the President are not an issue in Indian affairs. Moreover, the critical provisions of Indian treaties, such as recognition and guarantees of sovereignty and terri-

102. See L. Erades \& W. Gould, supra note 35, at 419-56; Comments by L. Sohn, 1969 AM. Soc'y InT'L L. Proc. 180. The Cherokee Tobacco itself involved the commercial aspects of an Indian treaty. In addition, two of the three cases cited therein for support also involved the commerce power, and these were the cases cited for the proposition that a statute may supersede a prior treaty. See supra note 57.

103. See E. Byrd, JR., supra note 78, at 31-33; L. Erades \& W. Gould, supra note 35, at 375-77. Commercial matters remain an area of special interest in international law; note the implied right of withdrawal from commercial treaties. See Vienna Convention, supra note 25, art. 56; International Law Commission Report, supra note 24, at 250-51.

104. See supra text accompanying note 36 .

105. See R. Barsh \& J. Henderson, supra note 5, at 92. In the Pacific Northwest, several treaties guarantee hunting rights both on-reservation and off-reservation. See generally D. GETCHES \& C. Wilkinson, supra note 3 , at $730-33$.

106. See supra text accompanying notes 83-103.

107. The Court views executive power over Indian affairs as following either explicitly or implicitly from congressional authorization. See, e.g., Arizona v. California, 373 U.S. 546, 598 (1963) (citing implied congressional consent as basis for President's power to reserve water rights by executive order); Sioux Tribe of Indians v. United States, 316 U.S. 317, 324-25 (1942) (citing implied congressional consent as basis for President's power to create reservations by executive order). This view is underscored by the Court's recent tendency to ground federal power over Indian affairs in specific clauses of the Constitution, see infra text accompanying notes 125-28, because the President, unlike Congress, has no specific grant of authority over Indian affairs, $c f$. C. Wilkinson, supra note 3, at 179 n.66 (arguing that President's war powers have been of limited importance since mid-nineteenth century). Felix Cohen apparently viewed the President's power over Indian affairs as administrative power delegated by Congress. See F: CoHEN, supra note 5, at 100-15.

Moreover, the Court, in expressing the view that treaty-statute conflicts were inherently political, relied in part on the fact that foreign states have international means of protecting their interests. See supra note 93 . Indians, however, lack this ability.

108. See, e.g., Seneca Nation of Indians v. United States, 338 F.2d 55, 59 (2d Cir. 1964) (Moore, J., dissenting), cert. denied, 380 U.S. 952 (1965); D. GeTChes \& C. Wilkinson, supra note 3, at $74,92,547$. 
tory, do not bear any resemblance to the commercial matters involved in the development of the rule. Thus, the last-in-time rule does not justify congressional abrogation.

\section{Lone Wolf v. Hitchcock: The Plenary Power Doctrine and Rebus Sic Stantibus}

Even after The Cherokee Tobacco, Congress seemed unsure of the scope of its authority to abrogate Indian treaties. ${ }^{109}$ In Lone Wolf $v$. Hitchcock, ${ }^{110}$ however, the Court clearly stated that Congress has broad power to abrogate Indian treaties. ${ }^{111}$ Lone Wolf involved a treaty setting aside a reservation and providing that no further land cessions would be valid without the approval of at least three-fourths of all adult males occupying the reservation. ${ }^{112}$ A later "agreement" provided for further cessions, ${ }^{113}$ and subsequent legislation opened up a large part of the reservation for homesteading. ${ }^{114}$ The Indians argued that treaty-guaranteed property rights could not be unilaterally abrogated by Congress without violating due process, ${ }^{115}$ and that the subsequent legislation amounted to unilateral abrogation because the "agreement" was obtained by fraud and lacked the three-fourths consent required by the treaty. ${ }^{116}$ In a somewhat disorganized opinion, the Court rejected the due process argument and thereby avoided the question of whether the "agreement" was valid. ${ }^{117}$

The Court began by implying that abrogation may be viewed as an exercise of Congress' plenary power:

Congress [possesses] a paramount power over the property of the Indians, by reason of its exercise of guardianship over their interests, and ... such authority might be implied, even though opposed to the strict letter of a treaty with the Indians. . . . Plenary authority over the tribal relations of the Indians has been exercised by Congress from the beginning, and the power has always been deemed a political one, not subject to be controlled by the judicial department of the government. ${ }^{118}$

109. This hesitancy may be explained by the fact that most treaties abrogated earlier involved commerce and immigration. See supra note 102 and accompanying text. The government often struggled to maintain the appearance that changes in treaties were due to "agreement" rather than unilateral congressional action. A good example is the attempt to obtain the Black Hills by "agreement." See United States v. Sioux Nation of Indians, 448 U.S. 371, 374-84 (1980).

110. 187 U.S. 553 (1903).

111. Congress apparently viewed this decision as an enlargement of its powers. See Rosebud Sioux Tribe v. Kneip, 430 U.S. 584, 587-88, 594-95 \& n.17, 598 \& n.19 (1977).

112. Treaty of Oct. 21, 1867, arts. II, XII, 15 Stat. 581, 582, 585.

113. Act of June 6,1900 , ch. $813, \S 6,31$ Stat. 672,676 .

114. Act of Mar. 3, 1901, ch. 846, 31 Stat. 1093; Act of Mar. 3, 1901, ch. 832, 31 Stat. 1058, 1078-79; Act of Jan. 4, 1901, ch. 8, 31 Stat. 727.

115. 187 U.S. at 564

116. Id. at 554-64.

117. Id. at 567-68.

118. Id. at 565 . 
After relying on the last-in-time rule, ${ }^{119}$ the Court offered yet a third justification, one closely resembling rebus sic stantibus, the doctrine of changed circumstances:

The power exists to abrogate the provisions of an Indian treaty, though presumably such power will be exercised only when circumstances arise which not only justify the government in disregarding the stipulations of the treaty, but may demand, in the interest of the country and the Indians themselves, that it should do so. When, therefore, treaties were entered into between the United States and a tribe of Indians it was never doubted that the power to abrogate existed in Congress, and that in a contingency such power might be availed of from considerations of governmental policy, particularly if consistent with good faith towards the Indians. ${ }^{120}$

Note that the Court suggests that the doctrine may be invoked because of the interests of the nation as a whole or the obligations of the United States as guardian.

\section{E. Critique of the Plenary Power Justification}

The view that congressional abrogation is an application of the plenary power doctrine is unpersuasive today because the doctrine has been significantly narrowed since Lone Wolf. The term "plenary power" has at least three meanings: exclusive power, preemptive power, and power that is unlimited both in the manner in which it may be used and as to the objectives that may be pursued. ${ }^{121}$ In Indian law, the term has been used with each meaning. ${ }^{122}$

The third meaning, however, has been considerably narrowed. ${ }^{123}$ The Lone Wolf Court spoke of plenary power over Indian affairs as unreviewable. ${ }^{124}$ In recent cases, however, the Court has exercised judicial review $^{120}$ and has specifically repudiated the notion that congressional ac-

119. Id. at 566 .

120. Id. (emphasis in original).

121. See Engdahl, State and Federal Power Over Federal Property, 18 ARIz. L. REv. 283, $362-66$ (1976).

122. See Newton, supra note 5, at 196 n.3; Comment, Federal Plenary Power in Indian Affairs After Weeks and Sioux Nation, 131 U. PA. L. Rev. 235, 240-50 (1982); supra note 107.

123. See C. Wilkinson, supra note 3, at 79-80; Newton, supra note 5, at 228-36; Comment, supra note 122 .

124. See supra text accompanying note 118. See generally Newton, supra note 5, at 207-28; Comment, supra note 122 , at 238-50.

125. See, e.g., United States v. Sioux Nation of Indians, 448 U.S. 371, 409-23 (1980) (abrogation of treaty-protected property rights will be subjected to Fifth Amendment taking analysis when abrogation is not good faith exercise of guardian power); Delaware Tribal Business Comm. v. Weeks, 430 U.S. 73, 85 (1977) (applying rational basis test in equal protection challenge to statute unfavorable to Indians); Morton v. Mancari, 417 U.S. 535, 555 (1974) (applying rational basis test in equal protection challenge to statute favorable to Indians); see also Shoshone Tribe of Indians v. United States, 299 U.S. 476, 497 (1937) (right to interest on Fifth Amendment taking comes from Fifth Amendment itself and not from special jurisdictional statute); United States v. Sandoval, 231 U.S. 28, 46 (1913) 
tions in this area are unreviewable. ${ }^{126}$ The Court also has stated that Congress' power over Indian affairs is "drawn both explicitly and implicitly from the Constitution itself." ${ }^{127}$ Accordingly, modern decisions seek to ground congressional power in specific clauses of the Constitution. ${ }^{128}$ The Court's latest statement on abrogation, while quoting Lone Wolf, does not rely on the plenary power language, ${ }^{129}$ and the Court arguably has separated plenary power from the power to abrogate Indian treaties. ${ }^{130}$ The plenary power argument most closely resembles several of the arguments offered in favor of the last-in-time rule, particularly the separation of powers arguments, the argument from sovereignty, and the argument based on the nature of treaties. As such, it can be met with the same responses. ${ }^{131}$ Thus, the plenary power doctrine does not justify congressional abrogation. ${ }^{132}$

\section{F. Critique of the Rebus Sic Stantibus Justification}

The view that congressional abrogation is an application of rebus sic stantibus is problematic for several reasons. First, it is difficult to view congressional abrogation as treaty termination. There is great controversy about the power of Congress to terminate treaties. ${ }^{133}$ In any case, Congress has used explicit language when it has attempted to terminate international treaties, ${ }^{134}$ but only one Indian treaty was so abrogated. ${ }^{135}$ Treaty termination by one party may free the other party as well, ${ }^{136}$ but there is no suggestion in the decisions that the Indians are now free to disregard their treaty obligations. Unilateral treaty termination requires

(Congress may not bring community under plenary power by arbitrarily calling it Indian tribe); Choate v. Trapp, 224 U.S. 665 (1912) (statute making Indian land non-taxable created property right protected by Fifth Amendment); Jones v. Meehan, 175 U.S. 1 (1899) (title to land granted to Indian by treaty cannot be divested by subsequent legislation).

126. See United States v. Sioux Nation of Indians, 448 U.S. 371, 413 (1980); Delaware Tribal

Business Comm. v. Weeks, 430 U.S. 73, 84 (1977).

127. Morton v. Mancari, 417 U.S. 535, 551-52 (1974).

128. See Newton, supra note 5, at 230-31. For a general discussion of constitutional sources of power, see F. CoHEN, supra note 5, at 89-102.

129. See United States v. Dion, 476 U.S. 734,738 (1986).

130. See United States v. Sioux Nation of Indians, 448 U.S. 371, 410-15 (1980).

131. See supra text accompanying notes 69-75, 83-95.

132. Given that the Court relies on two other arguments in Lone Wolf, it may be that plenary power merely provides the jurisdictional basis for the statute at issue. Another possibility is that the Court is referring to the fact that the United States holds the ultimate fee in Indian lands, subject to an Indian right of use and occupancy. See Johnson \& Graham's Lessee v. M'Intosh, 21 U.S. (8 Wheat.) 543, 571-92 (1823). The trouble with the latter explanation is that the issue in Lone Wolf did not involve the ultimate fee, but rather the right of use and occupancy.

133. See supra text accompanying note 26 .

134. See Act of June 5, 1920, ch. 250, § 34, 41 Stat. 988, 1007; Act of Mar. 4, 1915, ch. 153, § 16, 38 Stat. 1164, 1184; Act of Aug. 5, 1909, ch. 6, § 4, 36 Stat. 11, 83; Joint Resolution of Jan. 18, 1865, 13 Stat. 566; Joint Resolution of Apr. 27, 1846, 9 Stat. 109; Act of July 7, 1798, ch. 67, 1 Stat. 578.

135. V. Deloria, JR. \& C. Lytle, supra note 1, at 43 (citing Act of Feb. 16, 1863, ch. 37, § 1, 12 Stat. 652, 652).

136. See supra text accompanying note 24 . 
formal notice, ${ }^{137}$ but there is no record of this having been done in the case of Indian treaties. ${ }^{138}$ It is plausible that the reason favoring formal notice by the head of state-namely, that states interact through heads of state-requires only that Indians be given notice by Congress, which is deemed by the plenary power doctrine ${ }^{139}$ to be the head of state in Indian affairs. However, this would imply an express statement principle, which the Court has thus far refused to impose. ${ }^{140}$

Second, the conditions for invoking rebus sic stantibus are rarely satisfied in the Indian context. ${ }^{141}$ The doctrine of rebus sic stantibus ${ }^{\mathbf{1 4 2}}$ holds that a treaty may be terminated due to a fundamental change in circumstances that has occurred since the making of the agreement. ${ }^{143}$ The change must have been unforeseen, ${ }^{144}$ but it could be argued that the United States was aware of the changed circumstances under which many Indian treaties might be claimed to be terminated. ${ }^{145}$ The terminated treaty obligations must be unperformed ${ }^{146}$ for example, the doctrine would not cover treaties setting a boundary. ${ }^{147}$ Thus, the boundary setting provisions of Indian treaties arguably are outside the scope of the doctrine, ${ }^{148}$ as are provisions recognizing sovereignty or guaranteeing mineral rights. In addition, the effect of the change must be to transform radically

137. See sources cited supra note 25. Congressional terminations often direct the President to give formal notice. See, e.g., Act of June 5, 1920, ch. 250, § 34, 41 Stat. 988, 1007; Act of Mar. 4, 1915, ch. 153, § 16, 38 Stat. 1164, 1184; Act of Aug. 5, 1909, ch. 6, § 4, 36 Stat. 11, 83; Joint Resolution of Jan. 18, 1865, 13 Stat. 566; Joint Resolution of Apr. 27, 1846, 9 Stat. 109.

138. The one termination of an Indian treaty did not direct the President to give formal notice. See Act of Feb. 16, 1863, ch. 37, § 1, 12 Stat. 652, 652.

139. See supra text accompanying notes 107, 121-28.

140. See United States v. Dion, 476 U.S. 734, 738-39 (1986) (express statement is preferable but not required for abrogation). For other doctrinal justifications of an express statement principle, see Wilkinson \& Volkman, supra note 1.

141. See Clinebell \& Thomson, supra note 41, at 699-700; Higgins, International Law Consideration of the American Indian Nations by the United States, 3 ARIz. L. REv. 74, 84 (1961).

142. For more detailed discussions of this doctrine, see International Law Commission Report, supra note 24, at 256-68; Haraszti, Treaties and the Fundamental Change of Circumstances, 146 RECuEIL. DES Cours 1 (1975); Draft Convention on the Law of Treaties, and Comments, 29 AM. J. INT'L. L. SUPP. 653, 1096-1126 (1935).

The usual argument advanced in favor of the doctrine is that if international law provided no way to terminate an unduly burdensome treaty, it is likely that parties would take action outside of the law. See International Law Commission Report, supra note 24, at 256-58. For other justifications, see Haraszti, supra, at 46-60.

143. The circumstances must have been an essential basis of the consent to be bound by the treaty. See Case of the Free Zones of Upper Savoy and the District of Gex (Fr. v. Switz.), 1932 P.C.I.J. (ser. A/B) No. 46, at 156-58 (judgment of June 7); Restatement (THIRD), supra note 23, § 336; Vienna Convention, supra note 25 , art. 62.

144. See Restatement (ThiRd), supra note 23, § 336; Vienna Convention, supra note 25, art. 62; 1 L. OPPENHEIM, supra note 19, at 939.

145. See, e.g., W. WashbuRn, The Indian In AmERICa 170 (1975) (noting debate on whether westward expansion was foreseen, but suggesting that expansion was always considered possible).

146. See Restatement (ThIRD), supra note 23, § 336; Vienna Convention, supra note 25, art. 62; Haraszti, supra note 142 , at 68.

147. See Restatement (ThiRd), supra note 23, § 336 comment b; Vienna Convention, supra note 25, art. 62; International Law Commission Report, supra note 24, at 259; Haraszti, supra note 142 , at $41,43,65-69$.

148. See Clinebell \& Thomson, supra note 41 , at 699. 
the extent of these obligations, ${ }^{149}$ and an argument of economic necessity based on the need for more land ${ }^{150}$ is not likely to satisfy the requirement. ${ }^{101}$ The doctrine includes a "clean hands" principle, under which the party invoking the doctrine must not have wrongfully caused the change in circumstances, ${ }^{132}$ but it could be argued forcefully that in the Indian context the United States was the cause of many, if not most, substantial changes. ${ }^{183}$ Rebus sic stantibus requires that the party intending to invoke the doctrine has approached the other parties in a good faith effort to settle the problem, ${ }^{154}$ but many negotiations with the Indians were characterized by coercion, threats, and bribery on the part of the United States. ${ }^{155}$ Finally, international courts have generally avoided giving effect to the doctrine, usually on the ground that it was not applicable to the facts at hand, and the number of cases calling for application of the rule is small. ${ }^{158}$ Thus, rebus sic stantibus does not justify congressional abrogation.

\section{Congressional Abrogation of Indian Treaties: Reform}

Congressional abrogation of Indian treaties should be viewed as supersession by a subsequent statute, but the power should be limited by a "last-in-time plus" rule-the last-in-time rule supplemented by an express statement rule and a requirement of a justification acceptable for terminating treaties under international law. ${ }^{167}$ This scheme represents a reasonable synthesis that takes into account the previous discussion. ${ }^{158}$ In-

149. See Restatement (ThIRD), supra note 23, § 336; Vienna Convention, supra note 25, art. 62.

150. There is little doubt that many treaties were abrogated because of the desire for more land. See, e.g., Wilkinson \& Volkman, supra note 1, at 611 n.47.

151. See Fisheries Jurisdiction (U.K. v. Ice.), 1973 I.C.J. 3, 21, 61 (judgment of Feb. 2) (rejecting claim that threat to national economy constituted radical transformation).

152. See Restatement (ThIRD), supra note 23, \$336 comment b; International Law Commission Report, supra note 24, at 260.

153. See Clinebell \& Thomson, supra note 41, at 699-700; Higgins, supra note 141, at 83-84; see also RESTATEMENT (THIRD), supra note $23, \S 336$ reporters' note 4 (aggressor cannot use resulting hostilities as rebus sic stantibus justification); W. WASHBURN, supra note 145, at 204-05 (discussing responsibility of United States in provoking wars with Plains Indians).

154. See Restatement (ThiRd), supra note 23 , $\$ 336$ comment f; Vienna Convention, supra note 25 , arts. 65,$66 ; 1 \mathrm{~L}$. OPPENHEIM, supra note 19, at 941-42; Haraszti, supra note 142, at 83-85.

155. See United States v. Sioux Nation of Indians, 448 U.S. 371, 374-84 (1980); Choctaw Nation v. Oklahoma, 397 U.S. 620, 630-31 (1970); W. WASHBURN, supra note 145, at 101-02; Wilkinson \& Volkman, supra note 1 , at 609-11.

156. See Restatement (Second) of the Foreign Relations Law of the United States $\S 153$ comment a (1965); 1 L. OPpenHeIM, supra note 19, at 940.

157. For a list of these justifications, see supra text accompanying note 24 . If the Court modifies the plenary power doctrine to recognize a significant independent role for the President, then separation of powers concerns may support application of the traditional last-in-time rule. For a discussion of possible sources of presidential power, see V. Deloria, JR. \& C. LrTle, supra note 1, at 34-40. The traditional last-in-time rule, however, should be limited to the abrogation of off-reservation rights. See supra note 105 and accompanying text.

158. A functionally similar but doctrinally distinct position is to conclude from Sections I and II that congressional power to abrogate Indian treaties should be limited to treaty termination. The problem with this position is that it leaves international treaties subject to the last-in-time rule, and it 
deed, the Court's admission that the last-in-time rule is not derived from the Constitution ${ }^{169}$ can be seen as a recognition that the exact nature of the rule is subject to the doctrinal considerations examined above. Moreover, the increased protection is consistent with the Court's increased protection of Indian treaties in other areas. ${ }^{\mathbf{1 6 0}}$

Presumably, most abrogations would occur under rebus sic stantibus, based on changed circumstances that affect the interests of the nation as a whole or the obligations of the United States as guardian. ${ }^{\mathbf{1 6 1}}$ Other abrogations might occur, for example, by consent of the parties. ${ }^{162}$ Whether the necessary conditions are satisfied would be a question for the courts. ${ }^{163}$

This scheme would result in a heavier emphasis on negotiation, both because Congress would have a burden of justification and because it may be politically difficult to pass statutes with express statements of abrogation. But Indians have been willing to discuss treaty disputes, ${ }^{164}$ and Indian leaders have put forward concrete proposals for reinstituting the negotiation process. ${ }^{165}$

The proposed limits would affect the plenary power doctrine in several ways. They would diminish congressional power over Indian rights. On the other hand, they do recognize extensive congressional power over Indian treaties, a power that is hotly contested with respect to international treaties. ${ }^{108}$ Furthermore, the proposal allows the guardian responsibility

is doubtful that the framers of the Constitution, whatever their feelings about the rule, would have felt that international treaties could be superseded by statute but that Indian treaties could not be. One could respond that the "last-in-time plus" rule should apply to both, that the last-in-time rule should not apply to international treaties, or that the thoughts of the framers are not relevant. However, the first response needs more justification, and the last two responses sharply pose the difficult doctrinal question of whether a treaty can trump the Constitution, assuming that a treaty can trump both prior and subsequent statutes.

159. See supra text accompanying note 55 .

160. See supra text accompanying notes 44-50.

161. Rebus sic stantibus would be relevant, for example, when a federal wildlife conservation statute conflicts with treaty hunting rights. See generally Coggins \& Modrcin, Native American Indians and Federal Wildlife Law, 31 STAN. L. REv. 375 (1979); Pitt, Eagles and Indians: The Law and the Survival of a Species, 5 PuB. LAND L. Rev. 100 (1984); Walker, On-Reservation Treaty Hunting Rights: Abrogation v. Regulation by Federal Conservation Statutes-What Standard?, 26 NAT. ResourCes J. 187 (1986).

162. Many Indian treaties contain clauses holding previous treaties to be superseded. See, e.g., Treaty of Apr. 29, 1868, art. XVII, 15 Stat. 635, 640.

163. The courts already determine whether action is a legitimate exercise of the guardian authority in deciding whether a Fifth Amendment taking has occurred. See, e.g., United States v. Sioux Nation of Indians, 448 U.S. 371, 409-23 (1980). It is plausible that the courts, in deciding whether proffered rebus sic stantibus justifications are legitimate, should give some deference to a congressional finding. The courts could apply a rational basis test, which would be consistent with scrutiny in other areas of Indian affairs. See Delaware Tribal Business Comm. v. Weeks, 430 U.S. 73, 85 (1977); Morton v. Mancari, 417 U.S. 535, 555 (1974); G. WilkInSON, supra note 3, at 82 . However, the inquiries might require different standards. See Sioux Nation, 448 U.S. at 413 n.28.

164. See sources cited supra note 108.

165. See V. Deloria, JR., supra note 7, at 48-53, 249-63.

166. See sources cited supra note 26. 
to be used as an independent basis for abrogation under rebus sic stantibus. ${ }^{167}$

In addition to the doctrinal arguments examined above, the increased protection of Indian treaties is reasonable given the complex status and history of the Indians. Early international law considered indigenous peoples to be sovereign nations capable of treaty relations, ${ }^{188}$ and today there is a growing rerecognition of the fundamental rights of native populations. ${ }^{169}$ Even the young United States treated the Indians as equal powers. ${ }^{170}$ Until the early nineteenth century, Indians negotiated from a position of strength because of their physical power and the fact that they could ally themselves with the European powers. ${ }^{171}$ With the removal of the Europeans, Indians found themselves at a disadvantage in the negotiation process, ${ }^{172}$ and increasingly treaties were imposed upon them. ${ }^{173}$ There is something particularly unseemly about the United States unilaterally abrogating treaties, many of which it imposed, with a people whose treatment only can be described as the nightmare of the American dream. ${ }^{174}$

\section{CONCLUSION}

Justice Black wrote: "Great nations, like great men, should keep their word."175 This Note proposes no more than that the United States be required to "keep its word" as that phrase is properly understood in the Indian context.

167. In addition, some deference might be given to congressional findings. See supra note 163 .

168. See Clinebell \& Thomson, supra note 41, at 680-81; Williams, The Medieval and Renaissance Origins of the American Indian in Western Legal Thought, 57 S. CAL. L. Rev. 1 (1983); Note, supra note 3 , at 254-55.

169. See Standard-Setting Activities: Evolution of Standards Concerning the Rights of Indigenous Populations: Report of the Working Group on Indigenous Populations, U.N. Doc. E/CN.4/ Sub.2/AC.4/1987/WP.1/Add.1 (1987) (collecting provisions of international agreements concerning rights of indigenous populations). If recognition of these rights constitutes an international norm, congressional power over Indian affairs may be limited by international law. See Paust, Rediscovering the Relationship Between Congressional Power and International Law: Exceptions to the Last in Time Rule and the Primacy of Custom, 28 VA. J. INr'L L. 393, 418-43 (1988).

170. See Worcester v. Georgia, 31 U.S. (6 Pet.) 515, 548-49 (1832); Note, supra note 3, at 255 \& n.141.

171. See W. WASHBuRN, supra note 145, at 126-69; Wilkinson \& Volkman, supra note 1, at 608-09.

172. See Wilkinson \& Volkman, supra note 1, at 609-11 \& n.42 (discussing language barrier and increasing use of threats, coercion, bribery, and fraud).

173. See Choctaw Nation v. Oklahoma, 397 U.S. 620, 630-31 (1970); W. WASHBuRN, supra note 145, at 101-02; Wilkinson \& Volkman, supra note 1, at 609-11.

174. Cf. Cohen, The Erosion of Indian Rights, 1950-53: A Case Study in Bureaucracy, 62 YALE L.J. 348, 390 (1953) ("TT]he Indian plays much the same role in our American society that the Jews played in Germany."). The original Indian population was devastated by disease and a systematic policy of cultural extermination. See, e.g., W. WASHBURN, supra note 145, at 104-07, 233-49. For a brief history of federal Indian policy, see F. Cohen, Handbook of Federal Indian Law 47-206 (3d ed. 1982).

175. Federal Power Comm'n v. Tuscarora Indian Nation, 362 U.S. 99, 142 (1960) (Black, J., dissenting). 